\title{
Physico-chemical changes during processing and storage of UHT milk
}

\author{
Suvartan Ranvir ${ }^{1}$, Rajan Sharma ${ }^{2}$, Kamal Gandhi $^{2}$, Pranali Nikam ${ }^{2}$ and Bimlesh Mann ${ }^{2}$
}

Received: 20 June 2020 / Accepted: 19 December 2020 / Published online: 28 February 2021

(C) Indian Dairy Association (India) 2021

\begin{abstract}
In this study, physico-chemical and heat induced changes during the preparation and storage of UHT milk were evaluated. Parameters such as $\mathrm{pH}$, acidity, viscosity, sedimentation, colloidal calcium $(\mathrm{Ca})$, colloidal magnesium $(\mathrm{Mg})$, hydroxyl methyl furfural (HMF), lactulose and color value were evaluated. During conversion of raw milk to UHT milk, there was slight increase in viscosity, colloidal $\mathrm{Ca}$, colloidal $\mathrm{Mg}$, HMF, lactulose and colour value, while decrease in $\mathrm{pH}$ value was observed. During storage of UHT processed milk there was significant $(p<0.001)$ increase in viscosity, $a$ value, $b$ value, HMF and lactulose content, whereas a significant $(p<0.001)$ decrease in $\mathrm{pH}$, colloidal $\mathrm{Ca}$, colloidal $\mathrm{Mg}$ and $L$ value was observed. Increase in acidity, sedimentation content and formation of Maillard browning products adversely affected the quality of UHT milk. These changes were noticed more in UHT processed milk stored at $30^{\circ} \mathrm{C}$ vis-à-vis $5^{\circ} \mathrm{C}$.
\end{abstract}

Keywords: UHT milk, Calcium, Magnesium, HMF, Lactulose, Sedimentation

\section{Introduction}

Ultra-high temperature (UHT) processing of milk is one of the promising heat processing technique for elongating the shelf life of milk. UHT processing of milk is carried out at high temperature $\left(135-150^{\circ} \mathrm{C}\right)$ for a short time (1-10 seconds), resulting in production of sterile milk which when packaged aseptically is stable for about

${ }^{1}$ Dairy Chemistry Division, Warner College of Dairy Technology, SHUATS, Prayagraj, UP, India

${ }^{2}$ Dairy Chemistry Division, National Dairy Research Institute Karnal132 001, Haryana, India

Rajan Sharma $(\square)$

Dairy Chemistry Division, ICAR-National Dairy Research Institute, Karnal, 132001 India

Email: rajansharma21@gmail.com ; Mob.9416120181
6 months at room temperature (Al-Saadi and Deeth, 2008; Ranvir et al. 2020a). During processing and storage of UHT milk, various physio-chemical and biochemical reactions take place, including Maillard reactions, degradation of lactose, hydrolysis of lipid, aggregation and denaturation of whey proteins, formation of $\beta$ lactoglobulin and k-casein complexes and disturbance of salt balance (Corredig and Dalgleish, 1996; Richards et al. 2014; Sakkas et al. 2014). Apart from these changes, heating process causes development of undesired colors and flavour (especially cooked) which significantly affects the nutritional and sensory quality of UHT milk (Elliott et al. 2003; Elliott et al. 2005; Al-Saadi and Deeth, 2008; Sakkas et al. 2014). These changes drastically affect the quality of UHT milk, which limits its shelf life and thus the consumer acceptance (Rauh et al. 2014; Gaur et al. 2018; Sunds et al. 2018). The heat sensitive components, which are already present or develop in milk during heat processing, allow a direct and quantitative assessment of the processing impact without the detailed knowledge of the actual heat treatment history of the product are called as heat load indicators or thermal time integrator's (TTIs) (Claeys et al. 2002). TTIs can be categorized into two groups; first one is type- I and another one is type- II indicators. Type I-indicators are heat sensitive components such as whey proteins, vitamins, enzymes etc. During processing and storage, these components undergo inactivation, degradation and denaturation. Type II-indicators are those which are not originally present or present at a low level and are developed during processing and storage of heated milk and milk products e.g. HMF and lactulose (Elliott et al. 2003; Mayer et al. 2010; Sakkas et al. 2014). Type I-indicators are more suitable parameters for the evaluation of low intensity heat processing conditions e.g. pasteurization, while type II-indicators are better for assessment of severe heat treatments, such as UHT processing (De Block et al. 1996; Sakkas et al. 2014; Meshram et al. 2018).

Mostly two types of problems occurs in UHT milk during its storage, the first one is age gelation and the second one is development of changes like off flavour, colour and nutritional loss. The rate of these changes is largely dependent on the storage time and temperature. They cause adverse impact on the quality of UHT milk, thus limiting consumer acceptance (Corredig and Dalgleish, 1996; Richards et al. 2014; Sakkas et al. 2014; Deeth and Lewis, 2017; Ranvir et al. 2020b). Some of the researchers 
reported that during storage of UHT milk, there occurs reduction in sweet taste and development of sugary aromatic flavor (Clare et al. 2005; Jensen et al. 2015). The present study has been planned to assess the physico-chemical changes during conversion of raw milk to UHT milk and impact of storage time and temperature on the quality of UHT milk.

\section{Materials and Methods}

\section{Reagents}

Trifluoroacetic acid (TCA) was procured from Sisco Research Laboratories Pvt. Ltd, India. Sodium acetate was procured from Loba chemie, India. Other chemicals required in the study were procured from Sigma-Aldrich, Germany. All sample preparations and measurements were carried out using double distilled water (Cascada water purifier, UK) having conductance of $0.055 \mu \mathrm{S} /$ $\mathrm{cm}^{2}$.

\section{Collection of milk samples}

Raw milk and subsequently pasteurized and UHT processed (by indirect method) toned milk samples were collected from Verka dairy plant, Chandigarh, India. Raw and pasteurized milk were analyzed for their physico-chemical parameters and heat induced components. UHT milk was produced by heating milk at $140^{\circ} \mathrm{C}$ for $4 \mathrm{~s}$ by using an indirect tubular heat exchanger (STORK, Netherlands). Nine UHT milk (fat 3.0\% and 8.5\% SNF) samples were brought to the laboratory on the day of manufacture and divided into two groups; first group was stored at $5^{\circ} \mathrm{C}$ and second group was stored at $30^{\circ} \mathrm{C}$. Samples were examined at a regular interval of one month till 4 months of storage.

\section{pH}

The $\mathrm{pH}$ was determined in UHT milk by using Lab India $\mathrm{pH}$ analyzer (M-420, Cyberscan pH Tutor, EUTECH Instruments, Thermo Fisher Scientific, Mumbai, India) with combined electrode at $20 \pm 2^{\circ} \mathrm{C}$. Prior to use, the $\mathrm{pH}$ meter was calibrated with standard buffer solution of $\mathrm{pH} 4,7$ and 11 .

\section{Acidity}

Titratable acidity of milk samples was determined as per the procedure described in BIS (IS: 1479 (part-1) 2016).

\section{Viscosity}

The viscosity was measured at $20^{\circ} \mathrm{C}$ under constant conditions using Ostwald viscometer in athermostatically controlled water bath.

\section{Sedimentation}

Sedimentation test was carried out as per the method suggested by Hassan et al. (2009). The UHT milk sample was drain out from the cartons by leaving the bottom $4 \mathrm{~cm}$. The cartons were then inverted for about 10 minutes, up righted and kept in the exhaust hood to dry. The cartons were allowed to dry for 48 hours after opening the bottom flaps or wings of cartons to facilitate the drying of any sediment entrapped there. The cartons were weighed and then washed thoroughly to remove any sediment or residue adhering to the container. The washed cartons were again dried and weighed.

\section{Colloidal Ca and colloidal magnesium content}

UHT milk samples were defatted by centrifugation (Centrifuge $5810 \mathrm{R}$, Eppendorf, Sigma-Aldrich, Germany) at 4000xg for $10 \mathrm{~min}$ at $4{ }^{\circ} \mathrm{C}$ and skim milk was ultrafiltered with Amicon ${ }^{\circledR}$ Ultra-15, 10KDa Centrifugal Filter Devices (Merck, Germany) using centrifuge (@5000xg, $40 \mathrm{~min}, 25^{\circ} \mathrm{C}$ ). The permeate was discarded and retentate was analyzed for colloidal $\mathrm{Ca}$ and $\mathrm{Mg}$ content by using atomic absorption spectrometry (AA-7000; Shimadzu, Japan) as described in International Organization for Standardization (ISO, 8070 2007).

\section{HMF}

Total HMF content in UHT milk was determined using the method suggested by Cais-Sokolinska (2005). Ten millilitre UHT milk sample was acidified with $5 \mathrm{ml} 0.3 \mathrm{~N}$ oxalic acid followed by heating at $100^{\circ} \mathrm{C}$ for $60 \mathrm{~min}$. Content was then cooled to room temperature and mixed with $5 \mathrm{ml}$ of $40 \%$ trichloroacetic acid solution. The mixture was thoroughly mixed and filtered thorough Whatman paper No. 42 filter paper. One millilitre of aqueous solution of TBA $(0.05 \mathrm{M})$ was then added to $4 \mathrm{ml}$ of the filtrate. The solution was mixed thoroughly and incubated in water bath maintained at $40^{\circ} \mathrm{C}$ for $40 \mathrm{~min}$. It was then cooled to room temperature and absorbance was measured at $443 \mathrm{~nm}$.

\section{Lactulose}

The lactulose content was measured by enzymatic method using kit (Cat No: K-LACTUL) procured from Megazyme, Bray, Wicklow.

\section{Color Value}

Tristimulus spectrophotometer Hunter Lab model Color Flex ${ }^{\circledR}$ [Hunter Associates Laboratory Inc., VA, U.S.A with software (version 4.10)] was used for measuring the color of UHT milk and the results were expressed in terms of the CIE-LAB system according to the method of Popov-Raljic et al. (2008). The instrument was standardized in day light at reflectance angle of $10^{\circ}$ (illuminant D65/10 ${ }^{\circ}$ standard observer). The instrument was calibrated with standard black and white tiles as specified by the manufacturer. The light source was dual beam xenon flash lamp. Measurements were made on the milk sample taken in a glass sample cup (10 cm height and $6 \mathrm{~cm}$ diameter) supplied with the instrument by filling it to a fixed level (up to $3 \mathrm{~cm}$ ) for each sample. 


\section{Statistical analysis}

The results of physico-chemical changes during preparation and storage of UHT milk were compared using two-way ANOVA and that obtained between raw, pasteurized and freshly processed UHT milk through one-way ANOVA employing Bonferroni PostTests to compare results of different months using Prism Graph Pad (Prism version 7.01) software.

\section{Results and Discussion}

Assessment of the changes in physico-chemical parameters and production of heat induced components during pasteurization and UHT treatment is required to understand their impact on quality of milk. The changes in physico-chemical and heat induced parameters of raw milk, subsequently pasteurized and UHT processed milk are given in Table 1. During heating of milk, different chemical, physical and biochemical reactions take place. Comparing raw, pasteurized and UHT milk, there was a nonsignificant $(p>0.05)$ change in acidity and viscosity, while the $a$ value, HMF and lactulose content showed a significant $(p<0.001)$ increase. HMF, colloidal $\mathrm{Ca}$ and colloidal $\mathrm{Mg}$ content was increased significantly $(p<0.05)$ in pasteurized and UHT milk as compared to that of raw milk (Table 1). Thus, pasteurization and UHT treatment cause several physico-chemical and heat induced changes in milk. Similar results were also obtained by Jeurnink and De Kruif(1993), Elliot et al. (2003), Pestana et al. (2003) Gaucher et al. (2008) and Oh and Deeth (2017). Ritota et al. (2017) reported increase in $\mathrm{pH}$, viscosity, $\mathrm{HMF}$, lactulose, colloidal $\mathrm{Ca}$, colloidal $\mathrm{Mg}$ and colour value and decrease in acidity during heating of milk. It is worth mentioning here that a small amount of lactulose $(7.09 \pm 0.071 \mathrm{mg} / \mathrm{L})$ was also observed in raw milk. Previous researchers (Elliott et al. 2003; Lan et al. 2010) have also reported this important indicator of heat treatment in raw milk. Increase in viscosity during heating may be due to the denaturation of whey proteins (Jeurnink and De Kruif, 1993) and increase in $\mathrm{pH}$ may be due to lower whey protein associating with the micelles (Pestana et al. 2003). Burton (1984) reported that increase in colloidal Ca because of ionic $\mathrm{Ca}$ combined with the phosphates or the denatured proteins turns into the colloidal $\mathrm{Ca}$ form while the $\mathrm{Ca}$ moves to the inside of casein micelles, reduced the content of the ultrafiltrable $\mathrm{Ca}$ accordingly. There was also increase in colloidal $\mathrm{Mg}$ due to their migration into the calcium phosphate microgranules as evidenced by the increase in the size of these particles (Oh and Deeth, 2017). Maillard reaction formed HMF, Lactulose during heating of UHT milk (Sakkas et al. 2014) and also formed brown-coloured pigments (pyralysins and melanoidin) which caused change in colour value (Popov-Raljic et al. 2008). 
pH

The $\mathrm{pH}$ of UHT milk samples stored at 5 and $30^{\circ} \mathrm{C}$ was determined by $\mathrm{pH}$ meter and the results are presented in Fig. 1(a). The $\mathrm{pH}$ value of freshly prepared UHT milk sample was observed to be $6.67 \pm 0.019$ which decreased significantly $(p<0.001)$ to $6.54 \pm 0.019$ and $6.45 \pm 0.032$ after storage for 4 months at 5 and $30^{\circ} \mathrm{C}$, respectively. It was observed that samples showed nonsignificant $(\mathrm{p}>0.05)$ decrease in $\mathrm{pH}$ value at $5^{\circ} \mathrm{C}$, while samples stored at $30^{\circ} \mathrm{C}$ showed a significant decrease $(\mathrm{p}<0.01)$ after one month of storage period. Decrease in $\mathrm{pH}$ during storage of UHT milk may be due to the dephosphorylation of casein micelles, breakdown of lactose, precipitation of calcium phosphate, and proteolysis (Al-Saadi and Deeth, 2008). Our results are agreeing with the corresponding results obtained by McMahon (1996) and Hassan et al. (2009). Aldubhany et al. (2014) also reported that $\mathrm{pH}$ of UHT milk decreased during storage. Decrease in $\mathrm{pH}$ value might be a major factor for causing gelation during storage of UHT milk. As previously reported by Hassan et al. (2009) at neutral $\mathrm{pH}(6.7)$, the casein micelles are stable, while the lowering of the $\mathrm{pH}$ leads to aggregation of casein micelles and formation of a gel.

\section{Acidity}

The acidity in UHT milk samples was determined by titration method and it was expressed in terms of percent lactic acid. The results of acidity in UHT milk sample stored at 5 and $30^{\circ} \mathrm{C}$ are presented in Fig. 1 (b). The acidity value of freshly prepared UHT milk sample was observed to be $0.124 \pm 0.025 \%$ lactic acid which increased significantly $(\mathrm{p}<0.001)$ to $0.144 \pm 0.017$ and $0.164 \pm 0.0006 \%$ after storage for 4 months at 5 and $30^{\circ} \mathrm{C}$, respectively. Moreover, the statistical analysis indicated that the storage period had a significant effect on titratable acidity. The acidity percentage increased significantly $(\mathrm{p}<0.001)$ during storage at both 5 and $30^{\circ} \mathrm{C}$ temperature. The sample stored at $30^{\circ} \mathrm{C}$ showed higher rate of increase as compared to that stored at $5^{\circ} \mathrm{C}$. The Maillard reaction takes place during processing and storage, which degrade the lactose into acids. Formic acid is responsible for increasing titratable acidity of milk during storage. Our results are in agreement with earlier study carried out by Aldubhany et al. (2014), who also reported that a progressive relation exists between the acidity of UHT milk samples and storage time and the rate of increase in acidity was slightly higher in UHT samples stored at room temperature as compared to sample stored under refrigeration.

\section{Viscosity}

Viscosity is an important property of any liquid food because of its direct impact on its appearance and consumer acceptance (DePeters and Cant, 1992). Casein micelles play an important role in determining the viscosity of skim milk (Clare et al. 2005); however factors like addition of $\mathrm{NaCl}$, pressure, reaction with sugars, ionic strength, $\mathrm{pH}$, and heat also affects the aggregation of the micelles which influences resistance to flow (Broyard and Gaucheron, 2015). Changes in the viscosity during storage of UHT milk are depicted in Fig. 2(a). Viscosity of freshly prepared UHT milk sample was found to be $1.64 \pm 0.029 \mathrm{cP}$ which increased significantly $(p<0.001)$ to $1.87 \pm 0.005$ and $2.01 \pm 0.009 \mathrm{cP}$ after storage for 4 months at 5 and $30^{\circ} \mathrm{C}$, respectively. It was observed that samples showed non-significant $(p>0.05)$ increase in the viscosity at $5^{\circ} \mathrm{C}$, while that stored at $30^{\circ} \mathrm{C}$ showed a significant increase $(\mathrm{p}<0.001)$ after one month of storage period. It was also noted that UHT milk samples stored at $30^{\circ} \mathrm{C}$ showed higher viscosity than that of the sample stored at $5^{\circ} \mathrm{C}$. Similar trends to our results of increase in viscosity was reported by Aldubhany et al. (2014), who also observed that higher increase in viscosity in UHT milk sample stored at $37^{\circ} \mathrm{C}$ than the sample stored at $4^{\circ} \mathrm{C}$. Increase in viscosity is directly related to the proteolysis and proteolysis results in gelation during storage of UHT milk which leads to increase in viscosity value (Datta and Deeth, 2001; Rauh et al. 2014)

\section{Sedimentation}

The quality of sediment depends on the raw milk and on the type and severity of the heat treatments. For any one type of process, the amount of sediment increases with the severity of the heat treatment (Sweetsur et al. 1975; Vankatachalm and MacMahon, 1991). The amount of sediment decreases with homogenization pressure (Robinson, 1994). Sedimentation results of UHT milk samples during storage at 5 and $30^{\circ} \mathrm{C}$ are illustrated in Fig 2 (b). Sedimentation content in freshly processed UHT milk was observed to be $0.102 \pm 0.006 \mathrm{~g}$ which was significantly $(\mathrm{p}<0.001)$ increased to $1.937 \pm 0.018$ and $3.417 \pm 0.026 \mathrm{~g}$ after storage for a period of 4 months at 5 and $30^{\circ} \mathrm{C}$, respectively (Fig. $2 \mathrm{~b}$ ). The higher increase in sedimentation value was observed after 2 months of storage at $30^{\circ} \mathrm{C}$. It was noted that sample stored at $30^{\circ} \mathrm{C}$ showed higher rate of increase of sedimentation than the sample stored at $5^{\circ} \mathrm{C}$. The increase in sedimentation value during storage of sample may be due to the aggregation of proteins or protein particles of various sizes (Malmgren et al. 2017; Gaur et al. 2018). Similar to our findings, Ramsey and Swartzel (1984), Malmgren et al. (2017) and Gaur et al. (2018) also reported that sediment formation during storage of UHT milk was increased with storage period.

\section{Colloidal Ca and colloidal Mg content}

The equilibrium of $\mathrm{Ca}$ and $\mathrm{Mg}$ between soluble and colloidal phase in milk is important for their bioavailability and stability (Aldubhany et al. 2014). Colloidal $\mathrm{Ca}$ and colloidal $\mathrm{Mg}$ content in milk are around 66.5 and 33\%, respectively (Tewari and Juneja 2007; Huppertz et al. 2017; Singh et al. 2019). The changes in colloidal fraction of $\mathrm{Ca}$ and $\mathrm{Mg}$ content in UHT milk samples stored at 5 and $30^{\circ} \mathrm{C}$ are presented in Fig.3 (a) and (b). Colloidal $\mathrm{Ca}$ was decreased significantly $(p<0.001)$ during storage from 

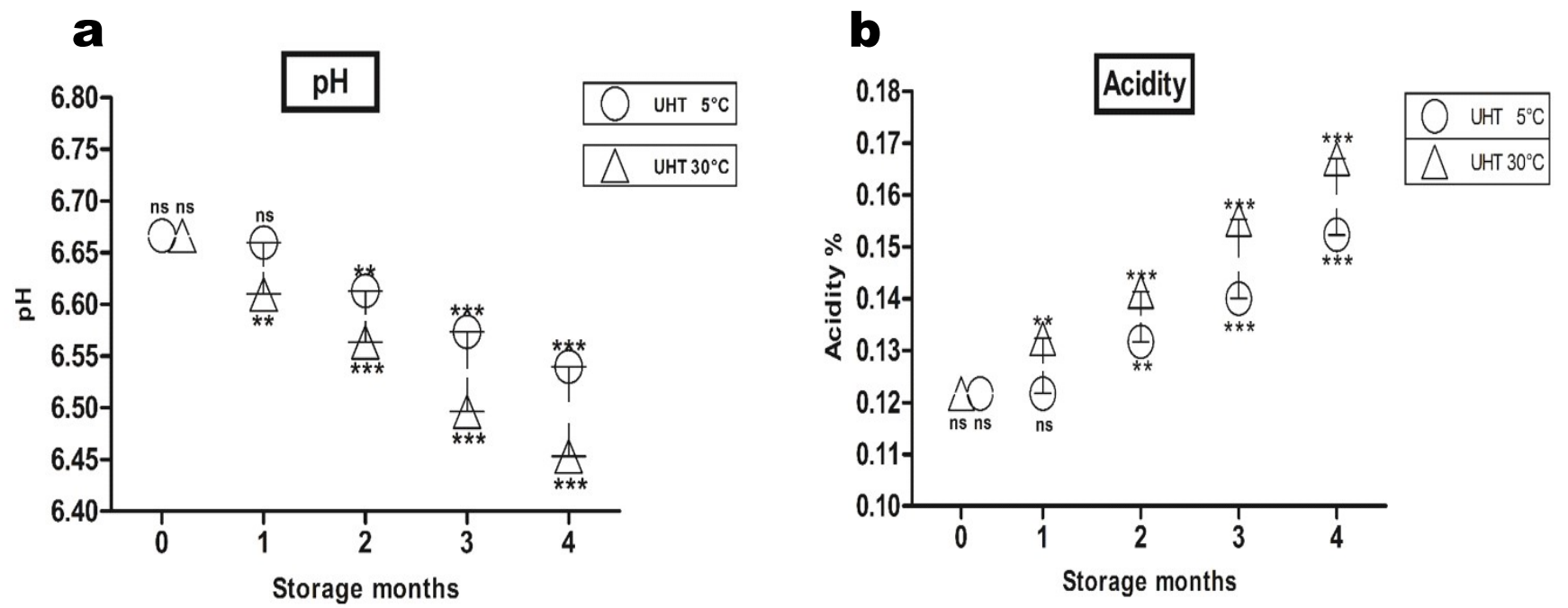

Fig. 1 (a). Changes in $\mathrm{pH}(\mathrm{b})$ Changes in acidity content during storage of UHT milk sample at $5^{\circ}(\mathrm{O})$ and $30^{\circ} \mathrm{C}(\Delta)$ after $0^{\text {th }}, 1^{\text {st }}, 2^{\text {nd }}, 3^{\text {rd }}$, and $4^{\text {th }}$ months.

Centre line shows the standard error; the circle $(\mathrm{O})$ shows the milk sample stored at $5^{\circ} \mathrm{C}$ and the triangle $(\Delta)$ shows the sample stored at $30^{\circ} \mathrm{C}$. All the readings were taken in triplicates. ${ }^{n s} \mathrm{p}>0.05,{ }^{*} \mathrm{p}<0.05, * * \mathrm{p}<0.01 * * * \mathrm{p}<0.001$.
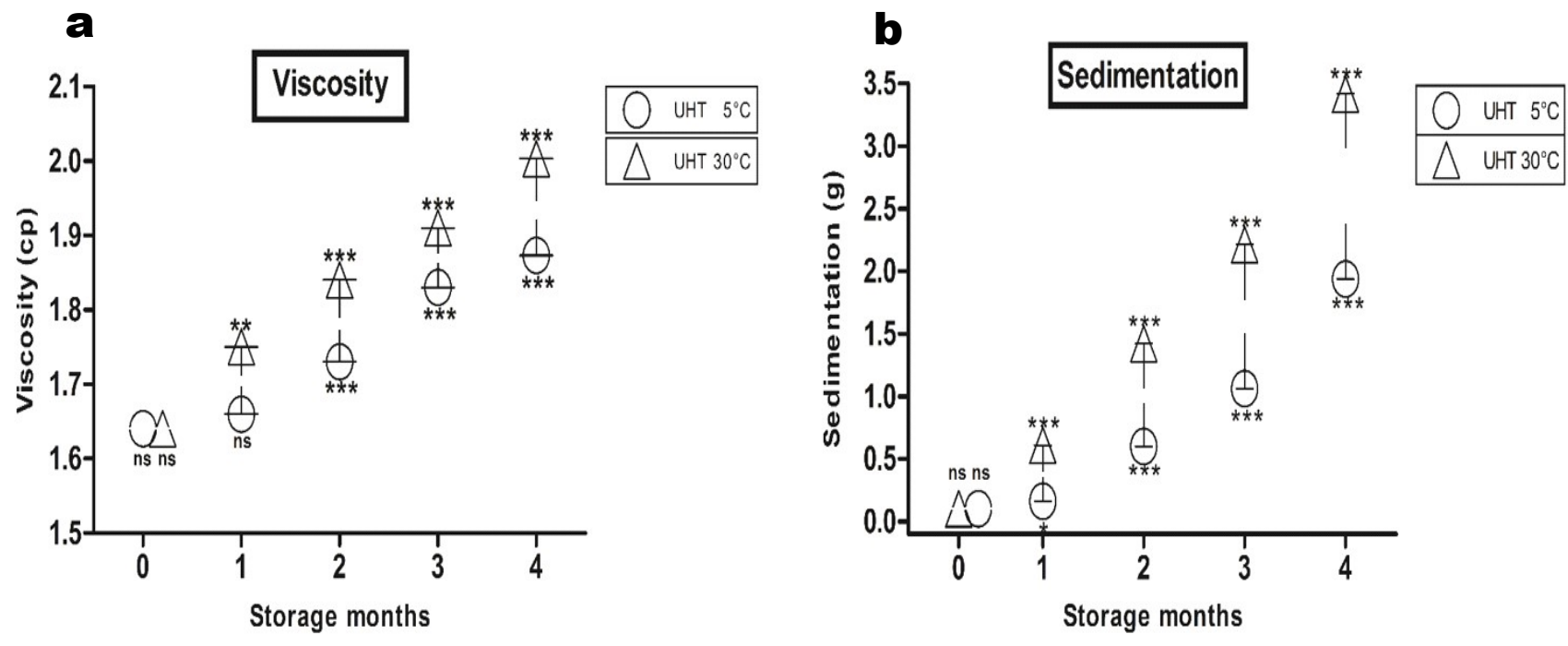

Fig 2 (a) Changes in viscosity (b) changes in sedimentation content of UHT milk sample at $5^{\circ}(\mathrm{O})$ and $30^{\circ} \mathrm{C}(\Delta)$ after $0^{\text {th }}, 1^{\text {st }}, 2^{\text {nd }}, 3^{\text {rd }}$, and $4^{\text {th }}$ months.

Centre line shows the standard error; the circle $(\mathrm{O})$ shows the milk sample stored at $5^{\circ} \mathrm{C}$ and the triangle $(\Delta)$ shows the sample stored at $30^{\circ} \mathrm{C}$. All the readings were taken in triplicates. ${ }^{\mathrm{ns}} \mathrm{p}>0.05,{ }^{*} \mathrm{p}<0.05,{ }^{*} \mathrm{p}<0.01 * * * \mathrm{p}<0.001$.

$77.2 \pm 0.282$ to $73.4 \pm 0.351$ and $71.3 \pm 0.312 \mathrm{mg} / 100 \mathrm{~mL}$ at $5^{\circ} \mathrm{C}$ and $30^{\circ} \mathrm{C}$, respectively after 4 month of storage (Fig 3a). Colloidal Mg also significantly $(\mathrm{p}<0.001)$ decreased during storage from $4.22 \pm 0.186$ to $3.41 \pm 0.326$ and $2.93 \pm 0.214 \mathrm{mg} / 100 \mathrm{~mL}$, at 5 and $30^{\circ} \mathrm{C}$, respectively after 4 month of storage (Fig. 3b). Sample stored at $30^{\circ} \mathrm{C}$ showed greater conversion of colloidal $\mathrm{Ca}$ and $\mathrm{Mg}$ phase to soluble $\mathrm{Ca}$ and $\mathrm{Mg}$ phase than that stored at $4{ }^{\circ} \mathrm{C}$. The changes in colloidal $\mathrm{Ca}$ contents may be due to decrease in $\mathrm{pH}$ values during storage, especially when the samples were stored at $30^{\circ} \mathrm{C}$. In concomitant to our results, Aldubhany et al. (2014) also reported that transfer of $\mathrm{Ca}$ and $\mathrm{Mg}$ from colloidal to soluble form occurs 

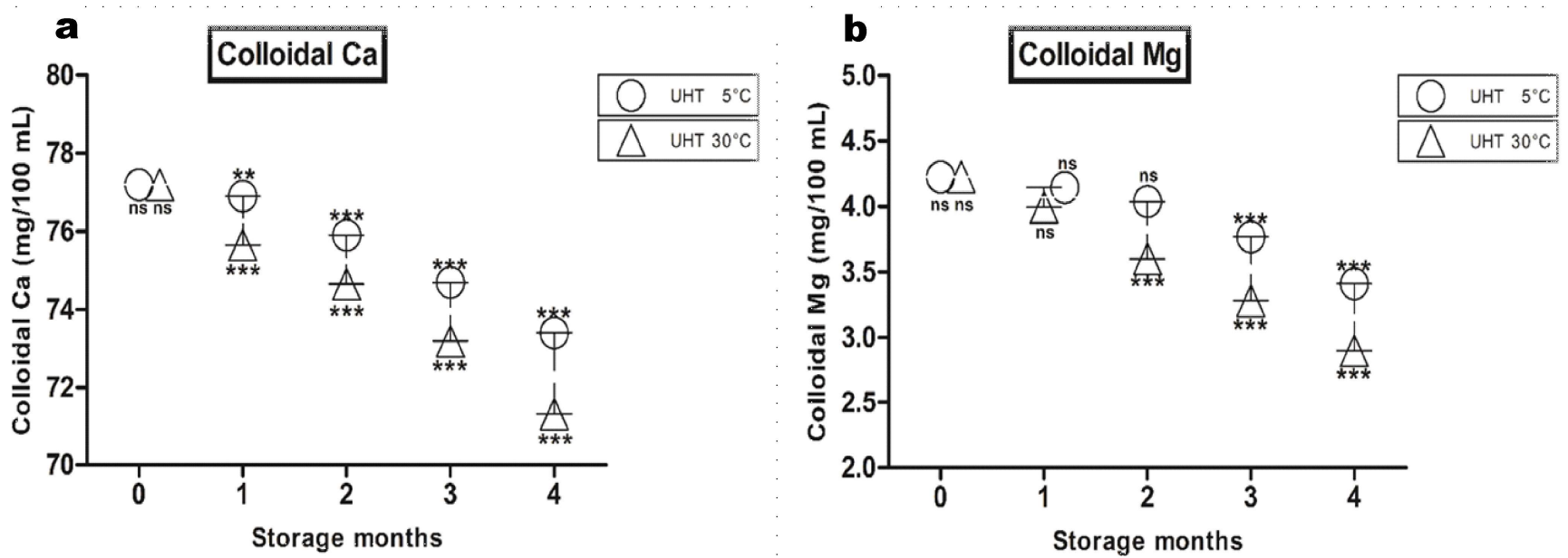

Fig. 3 (a) Changes in colloidal calcium (b) changes in colloidal magnesium content during storage of UHT milk sample at $5^{\circ}(\mathrm{O})$ and $30^{\circ} \mathrm{C}(\Delta)$ after $0^{\text {th }}, 1^{\text {st }}, 2^{\text {nd }}, 3^{\text {rd }}$, and $4^{\text {th }}$ months.

Centre line shows the standard error; the circle $(\mathrm{O})$ shows the milk sample stored at $5^{\circ} \mathrm{C}$ and the triangle $(\Delta)$ shows the sample stored at $30^{\circ} \mathrm{C}$. All the readings were taken in triplicates. ${ }^{n s} \mathrm{p}>0.05,{ }^{*} \mathrm{p}<0.05,{ }^{* *} \mathrm{p}<0.01 * * * \mathrm{p}<0.001$.
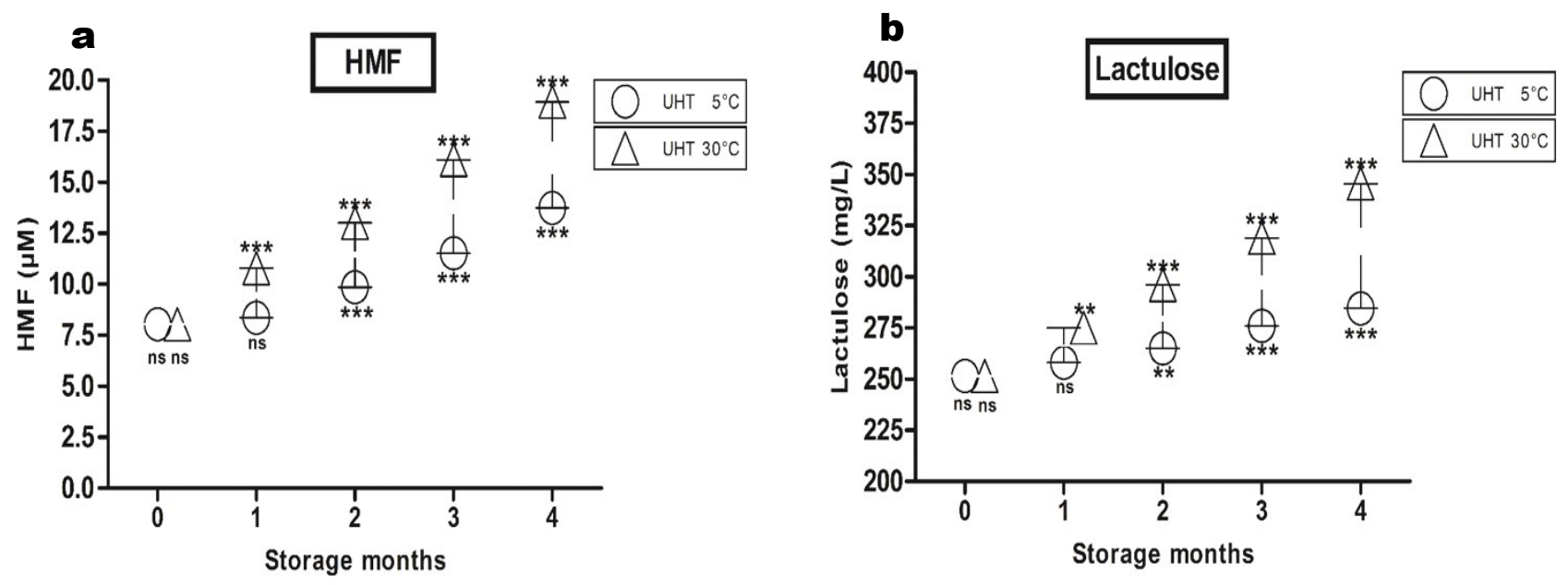

Fig. 4 (a) Changes in HMF content (b) changes in lactulose content during storage of UHT milk sample at $5^{\circ}(\mathrm{O})$ and $30^{\circ} \mathrm{C}(\Delta)$ after $0^{\text {th }}, 1^{\text {st }}, 2^{\text {nd }}, 3^{\text {rd }}$, and $4^{\text {th }}$ months.

Centre line shows the standard error; the circle $(\mathrm{O})$ shows the milk sample stored at $5^{\circ} \mathrm{C}$ and the triangle $(\Delta)$ shows the sample stored at $30^{\circ} \mathrm{C}$. All the readings were taken in triplicates. ${ }^{\mathrm{n}} \mathrm{p}>0.05,{ }^{*} \mathrm{p}<0.05, * * \mathrm{p}<0.01 * * * \mathrm{p}<0.001$.

with storage and that the changes were more pronounced in UHT milk sample stored at $37^{\circ} \mathrm{C}$ than that stored at 4 and $22^{\circ} \mathrm{C}$.

\section{HMF}

HMF is an important component used for assessing the intensity of heat treatment. It is also used as an indicator for degree of progress of the Maillard reaction. It is not present in raw milk or present only at trace level and formed during heating and storage of high heat treated milk and milk products (Albalá-Hurtado et al. 1997; Morales and Jiménez-Pérez, 1999; Morales et al. 2000;
Murata et al. 2007; Ritota et al. 2017). In earlier stage of Maillard reaction, there occurs condensation of carbonyl group of lactose and [-amino group of lysine residue, followed by development of intermediate product HMF (Morales et al. 2000; CaisSokolinska, 2005). Amadori rearrangement product (1-amino-1deoxy-2-ketoses) formed during severe heating is rapidly converted into HMF under acid conditions (Nursten, 2005). In this study, extent of HMF content was determined by using the method suggested by Cais-Sokolińska, (2005) and results are illustrated in Fig. 4 (a). The HMF content was significantly 
Table 2 Color $(L, a, b)$ value of UHT milk sample stored at $5^{\circ} \mathrm{C}$ and $30^{\circ} \mathrm{C}$ for 4 months

\begin{tabular}{lllll}
\hline $\begin{array}{l}\text { Storage period } \\
\text { (months) }\end{array}$ & $\begin{array}{l}\text { Storage } \\
\text { Temperature }\end{array}$ & $\boldsymbol{L}$ & $\boldsymbol{a}$ & $\boldsymbol{b}$ \\
\hline 0 & - & $87.62 \pm 0.091^{\mathrm{ns}}$ & $-1.80 \pm 0.042^{\mathrm{ns}}$ & $9.33 \pm 0.042^{\mathrm{ns}}$ \\
1 & $5^{\circ} \mathrm{C}$ & $87.27 \pm 0.155^{*}$ & $-1.04 \pm 0.021^{* * *}$ & $9.41 \pm 0.018^{\mathrm{ns}}$ \\
& $30^{\circ} \mathrm{C}$ & $86.52 \pm 0.127^{* * *}$ & $-0.81 \pm 0.077^{* * *}$ & $9.80 \pm 0.049^{* * *}$ \\
2 & $5^{\circ} \mathrm{C}$ & $86.22 \pm 0.12^{* * *}$ & $-0.95 \pm 0.027^{* * *}$ & $9.55 \pm 0.023^{* *}$ \\
3 & $30^{\circ} \mathrm{C}$ & $84.91 \pm 0.092^{* * *}$ & $-0.65 \pm 0.056^{* * *}$ & $9.90 \pm 0.029^{* * *}$ \\
& $5^{\circ} \mathrm{C}$ & $85.81 \pm 0.144^{* * *}$ & $-0.71 \pm 0.028^{* * *}$ & $9.69 \pm 0.042^{* * *}$ \\
4 & $30^{\circ} \mathrm{C}$ & $80.22 \pm 0.106^{* * *}$ & $0.030 \pm 0.023^{* * *}$ & $10.15 \pm 0.022^{* * *}$ \\
& $5^{\circ} \mathrm{C}$ & $84.57 \pm 0.106^{* * *}$ & $-0.55 \pm 0.027^{* * *}$ & $9.81 \pm 0.017^{* * *}$ \\
\hline
\end{tabular}

Superscript are significantly different, ${ }^{\mathrm{ns}} \mathrm{p}>0.05,{ }^{*} \mathrm{p}<0.05,{ }^{*} \mathrm{p}<0.01 * * * \mathrm{p}<0.001$ from each other.

$(\mathrm{p}<0.001)$ increased during storage from $8.03 \pm 0.035$ to 13.74 \pm 0.091 and $18.94 \pm 0.106 \mu \mathrm{mol} / \mathrm{L}$ at 5 and $30^{\circ} \mathrm{C}$, respectively after 4 month of storage. It was observed that there was about 1.7 times increase in the HMF content of the sample stored at $5^{\circ} \mathrm{C}$ and around 2.3 times increase in the sample stored at $30^{\circ} \mathrm{C}$. Higher content of $\mathrm{HMF}$ in sample stored at $30^{\circ} \mathrm{C}$ may be due to the higher rate of Maillard reaction at higher temperature. Our results are in agreement with the Cais-Sokolińska, (2005) who reported that HMF value almost doubled in the UHT milk stored at $20^{\circ} \mathrm{C}$ after 24 weeks. The author also revealed that increase in the $\mathrm{HMF}$ content was higher in sample stored at $20^{\circ} \mathrm{C}$ than that stored at 4 and $8^{\circ} \mathrm{C}$. Morales et al. (2000) reported that in freshly processed UHT milk sample, it is around 5.6-8.7 $\mu \mathrm{mol} / \mathrm{L}$. HMF is a product which originates from the Maillard reaction, and hence it can be assumed that, while the Maillard reaction progresses during UHT milk storage, the HMF content will proportionally increases (Morales and Jimenez-Perez, 1999).

\section{Lactulose}

Lactulose is a semi-synthetic disaccharide consisting of galactose and fructose molecule. During heating of milk and milk product lactose gets isomerized with the formation of lactulose (4-O-ß-D-galactopyranosyl-D-fructofuranose) by Lobry de Bruyn-Alberda van Ekenstein (LA) transformation (Hashemi and Ashtiani, 2010). Lactulose is considered to be a suitable indicator for differentiating UHT milk and pasteurized milk (Montilla et al. 2005). Fig. 4 (b) shows that the increase in lactulose concentration is greatly dependent on the storage time and temperature. Samples stored at $30^{\circ} \mathrm{C}$ showed increase in lactulose content than samples stored at $5^{\circ} \mathrm{C}$. Lactulose content in freshly processed UHT milk was observed to be $251 \pm 3.531 \mathrm{mg} / \mathrm{L}$ which was significantly $(\mathrm{p}<0.001)$ increased to $284 \pm 3.535 \mathrm{mg} / \mathrm{L}$ and $345 \pm 2.121 \mathrm{mg} / \mathrm{L}$ after storage for a period of 4 months at 5 and $30^{\circ} \mathrm{C}$, respectively. Comparing lactulose content of freshly processed UHT milk with samples stored over a period of 1 month, it was observed that samples stored at $5^{\circ} \mathrm{C}$ showed non-significant changes $(\mathrm{p}>0.05)$, while sample stored at $30^{\circ} \mathrm{C}$ showed a significant increase $(p<0.001)$ in lactulose content. Our results are in agreement with the previous study carried out by (Birlouez-Aragon et al. 1998; Morales et al. 2000; Elliott et al. 2003; Elliott et al. 2005; Sakkas et al. 2014) who found that the lactulose content in UHT milk is in the range of $50-850 \mathrm{mg} / \mathrm{L}$. Lactulose content up to $15 \mathrm{mg} / \mathrm{L}$ in pasteurized milk and $80 \mathrm{mg} / \mathrm{L}$ in high temperature pasteurized milk has been reported (Marconi et al. 2004; Feinberg et al. 2006). Simlar trend of considerable increase in the lactulose content during storage was also reported (Morales et al. 2000; Elliott et al. 2005; Feinberg et al. 2006). Morales and Jimenez-Perez (1999) observed that the maximum increase in lactulose content was at high temperatures and the highest value was recorded when milk was stored at 40 and $50^{\circ} \mathrm{C}$ for 90 days.

\section{Color value}

Heating process, storage condition and heat induced reaction like Maillard's reaction, causes physio chemical changes in milk, which impacts the color of milk (Popov-Raljic et al. 2008). The color determination denoted in $L, a, b$ value. $L$ represent for the index of lightness, $b(+)$ represent for yellow color while $b(-)$ represents for blue color. $A(+)$ represent values for red color whereas $a(-)$ represents for green color (Manzi et al. 2013). Changes in the $L$, $a$ and $b$ values of UHT milk samples during storage at 5 and $30^{\circ} \mathrm{C}$ are presented in Table 2. $L, a$ and $b$, values of freshly processed UHT milk was observed to be $87.62 \pm 0.091$, $-1.80 \pm 0.042$ and $9.33 \pm 0.042$. It was observed that $L$ value decreased significantly $(\mathrm{p}<0.001)$ to $84.57 \pm 0.106$ and $79.84 \pm 0.098$ at 5 and $30^{\circ} \mathrm{C}$, respectively after 4 months of storage. The $a$ value was increased significantly $(\mathrm{p}<0.001)$ to $-0.55 \pm 0.027$ and $0.18 \pm 0.018$ at 5 and $30^{\circ} \mathrm{C}$, respectively, while the $b$ value significantly $(\mathrm{p}<0.001)$ increased to $9.81 \pm 0.017$ and $10.42 \pm 0.070$ at 5 and $30^{\circ} \mathrm{C}$, respectively after 4 months of storage. It was observed that the sample showed significant $(<0.05)$ decrease in $L$ value and non-significant $(\mathrm{p}>0.05)$ change in the $b$ value at $5^{\circ} \mathrm{C}$, while that stored at $30^{\circ} \mathrm{C}$ showed a significant $(\mathrm{p}<0.001)$ change in both $L$ and $b$ value after one month of storage period. Sample stored at $30^{\circ} \mathrm{C}$ showed more changes in $L, a$ and $b$ value as compared to that stored at $5^{\circ} \mathrm{C}$ sample. Gaucher et al. (2008) also observed visual browning in milk samples during storage at 
$40^{\circ} \mathrm{C}$. Popov-Raljic et al. (2008) reported that the average psychometric chroma $b^{*}$ value was significantly higher $(\mathrm{p}<0.01)$ during storage of UHT milk with $3.2 \%$ milk fat.

\section{Conclusion}

In agreement with other studies, pasteurized milk showed less heat damage than the UHT processed milk sample. There was increase in acidity, viscosity, sedimentation value, while decrease in colloidal $\mathrm{Ca}$ and $\mathrm{Mg}$ during storage of UHT milk. There was continuous rise of heat induced components such as lactulose, HMF and colour value during storage of UHT milk. All these changes affected the quality of UHT milk during storage. Minimal changes were observed in that milk stored at $5^{\circ} \mathrm{C}$ rather than that stored at $30^{\circ} \mathrm{C}$. So, the study indicated that it is better to store UHT milk at refrigeration temperature to preserve its quality.

\section{Acknowledgement}

Authors thank the Department of Dairy Chemistry, ICARNDRI, Karnal for providing funds.

\section{References}

Al-Saadi J, Deeth HC (2008) Cross-linking of proteins and other changes in UHT milk during storage at different temperatures. Aust J Dairy Technol 63:93-99

Albalá-Hurtado S, Veciana-Nogués MT, Izquierdo-Pulido M, Vidal-Carou MC (1997) Determination of free and total furfural compounds in infant milk formulas by high-performance liquid chromatography. J Agric Food Chem 45: 2128-2133

Aldubhany TAW, Gouda E, Khattab A, Dabour N (2014) Effects of storage on some physico-chemical characteristics of UHT milk stored at different temperature. Alexandria Science Exchange 3:107-114

Birlouez-Aragon I, Nicolas M, Metais A, Marchond N, Grenier J, Calvo D (1998) A rapid fluorimetric method to estimate the heat treatment of liquid milk. Int Dairy J 8(9):771-777

Broyard C, Gaucheron F (2015) Modifications of structures and functions of caseins: a scientific and technological challenge. Dairy Sci Technol 95:831-862

Burton, H (1984). Reviews of the progress of dairy science: the bacteriological, chemical, biochemical and physical changes that occur in milk at temperatures of $100-150^{\circ}$ C. J Dairy Res 51:341363

Cais-sokolinska D, Pikul J, Dankow R, Wojtowski J (2005). Changes in some selected physico-chemical and sensory parameters of UHT milk during storage at different temperatures. Milchwissenschaft 60: $37-40$

Claeys WL, Van Loey AM, Hendrickx ME (2002) Kinetics of alkaline phosphatase and lactoperoxidase inactivation, and of betalactoglobulin denaturation in milk with different fat content. J Dairy Res 69: 541-553

Clare DA, Bang WS, Cartwright G, Drake MA, Coronel P, Simunovic J (2005) Comparison of sensory, microbiological, and biochemical parameters of microwave versus indirect UHT fluid skim milk during storage. J Dairy Sci 88: 4172-4182

Corredig M, Dalgleish DG (1996) Effect of different heat treatments on the strong binding interactions between whey proteins and milk fat globules in whole milk. J Dairy Res 63: 441-449
Deeth HC, Lewis MJ (2017) Changes during storage of UHT milk. High temperature processing of milk and milk products. John Wiley and Sons. pp 261-320

Datta N, Deeth HC (2001) Age gelation of UHT milk-a review. Food and Bioproducts processing 79:197-210

De Block J, Merchiers M, Van Renterghem R, Moermans R (1996) Evaluation of two methods for the determination of lactulose in milk. Int Dairy J 6: 217-222

DePeters EJ, Cant JP (1992) Nutritional factors influencing the nitrogen composition of bovine milk: A Review. J Dairy Sci 75:2043-2070

Elliott AJ, Dhakal A, Datta N, Deeth HC (2003) Heat-induced changes in UHT milks - Part 1. Aust J Dairy Technol 58: 3-10

Elliott AJ, Amenu B, Deeth HC (2005) Heat-induced and other chemical changes in commercial UHT milks. J Dairy Res 72: 442-446

Feinberg M, Dupont D, Efstathiou T, Louâpre V, Guyonnet JP (2006) Evaluation of tracers for the authentication of thermal treatments of milks. Food Chem 98: 188-194

Gaucher I, Mollé D, Gagnaire V, Gaucheron F (2008) Effects of storage temperature on physico-chemical characteristics of semi-skimmed UHT milk. Food Hydrocoll 22: 130-143

Gaur V, Schalk J, Anema SG (2018) Sedimentation in UHT milk. Int Dairy J 78: 92-102

Hashemi SA, Ashtiani FZ (2010) The isomerization kinetics of lactose to lactulose in the presence of sodium hydroxide at constant and variable pH. Food and Bioproducts Processing 88: 181-187

Hassan A, Amjad I, Mahmood S (2009) Microbiological and physicochemical analysis of different UHT milks available in market. Afr J Food Sci 3: 100-106

Huppertz T, Fox PF, Kelly AL (2017) The caseins: Structure, stability, and functionality. Proteins in Food Processing: Second Edition. pp 4992

IS 1479 (Part-1) (1977) (Reaffirmed 2016) Determination of titratable acidity in milk. Handbook of food analysis-dairy products. Bureau of Indian Standards. Delhi India: Simco printing press

ISO 8070 (2007) Milk and milk products determination of calcium, sodium, potassium and magnesium content -Atomic absorption spectrometric method. International organization for standardization

Jensen S, Jansson T, Eggers N, Clausen MR, Larsen LB, Jensen HB, Bertram HC (2015) Storage-induced changes in the sensory characteristics and volatiles of conventional and lactose-hydrolyzed UHT processed milk. Eur Food Res Technol 240: 1247-1257

Jeurnink TJ, De Kruif KG (1993) Changes in milk on heating: viscosity measurements. J Dairy Res 60: 139-150

Lan XY, Wang JQ, Bu DP, Shen JS, Zheng N, Sun P (2010). Effects of heating temperatures and addition of reconstituted milk on the heat indicators in milk. J Food Sci 75: C653-8

Manzi P, Di Costanzo M, Mattera M (2013) Updating nutritional data and evaluation of technological parameters of Italian milk. Foods 2: 254-273

Malmgren B, Ardö Y, Langton M, Altskär A, Bremer MG, Dejmek P,Paulsson M (2017) Changes in proteins, physical stability and structure in directly heated UHT milk during storage at different temperatures. Int Dairy J 71:60-75

Marconi E, Messia MC, Amine A, Moscone D, Vernazza F, Stocchi F, Palleschi G (2004) Heat-treated milk differentiation by a sensitive lactulose assay. Food Chemi 84: 447-450

Mayer HK, Raba B, Meier J, Schmid A (2010) RP-HPLC analysis of furosine and acid-soluble $\beta$-lactoglobulin to assess the heat load of extended shelf life milk samples in Austria. Dairy Sci Technol 90: 413-428

McMahon DJ (1996) Age-gelation of UHT milk: changes that occur during storage, their effect on shelf life and the mechanism by which agegelation occurs. Int Dairy Fed. pp 315-325 
Meshram BD, Asgar S, Adil S, Ranvir S (2018) Chemical markers for monitoring heat damage of processed milk. Int J Chem Stud 6: 2073-2081

Montilla A, Moreno FJ, Olano A (2005) A reliable gas capillary chromatographic determination of lactulose in dairy samples. Chromatographia 62: 311-314

Morales FJ and Jiménez-Pérez S (1999) HMF formation during heattreatment of milk-type products as related to milk fat content. J Food Sci 64: 855-859

Morales FJ, Romero C, Jiménez-Pérez S (2000) Characterization of industrial processed milk by analysis of heat-induced changes. Int $\mathrm{J}$ Food Sci Technol 35:193-200

Murata M, Totsuka H and Ono H (2007) Browning of furfural and amino acids, and a novel yellow compound, furpipate, formed from lysine and furfural. Biosci. Biotechnol. Biochem71: 1717-1723

Nursten H (2005) The Maillard reaction chemistry, biochemistry and implications. The Royal Society of Chemistry, Cambridge, UK

Oh HE, Deeth HC (2017) Magnesium in milk. Int Dairy J 71: 89-97

Pestana JM, Gennari A, Monteiro BW, Lehn DN, Souza CFVD, Anema SG, Elwood P (2003) UK food standards agency workshop report: The effects of the dietary n-6: n-3 fatty acid ratio on cardiovascular health. Am J Food Tech 10(6):1640-1646

Popov-Raljic JV, Lakic NS, Lalicic-Petronijevic JG, Barac MB, Sikimic VM (2008) Color changes of UHT milk during storage. Sensors 8: $5961-5974$

Ramsey JA, Swartzel KR (1984) Effect of ultra high temperature processing and storage conditions on rates of sedimentation and fat separation of aseptically packaged milk. J Food Sci 49: 257-262

Ranvir S, Sharma R, Gandhi K, Upadhyay N, Mann, B (2020a) Assessment of proteolysis in ultra-high temperature milk using attenuated total reflectance-Fourier transform infrared spectroscopy. Int J Dairy Technol 73: 366-375
Ranvir S, Sharma R., Gandhi K, Mann, B (2020b) Assessment of physicochemical changes in UHT milk during storage at different temperatures. J of Dairy Res 87: 243-247

Rauh VM, Sundgren A, Bakman M, Ipsen R, Paulsson M, Larsen LB and Hammershøj M (2014) Plasmin activity as a possible cause for age gelation in UHT milk produced by direct steam infusion. Int Dairy J 38: 199-207

Richards M, De Kock HL, Buys EM (2014) Multivariate accelerated shelflife test of low fat UHT milk. Int Dairy J 36: 38-45

Ritota M, Di Costanzo MG, Mattera M, Manzi P (2017) New trends for the evaluation of heat treatments of milk. J Anal Methods Chem 1864832

Robinson RK (1994) Modern Dairy Technology: Volume 1 Advances in Dairy Processing Vol 1 McGraw Hill Book Co Inc, New York, USA.

Sakkas L, Moutafi A, Moschopoulou E, Moatsou G (2014) Assessment of heat treatment of various types of milk. Food Chem 159: 293-301

Singh M, Sharma R, Ranvir S, Gandhi K, Mann B (2019). Profiling and distribution of minerals content in cow, buffalo and goat milk. Indian J Dairy Sci 72: 480-488

Sunds AV, Rauh VM, Sørensen J, Larsen LB (2018) Maillard reaction progress in UHT milk during storage at different temperature levels and cycles. Int Dairy J 77: 56-64

Sweetsur, AWM, White JCD (1975) Studies on the heat stability of milk proteins III. Effect of heat induced acidity in milk. J Dairy Sci 42: 73-88

Tewari G and Juneja VK (2007) Advances in Thermal and Non-Thermal Food Preservation. John Wiley and Sons

Vankatachalm, N. and MacMahon, D.J. (1991) Effect of lactose concentration on age-gelation of UHT sterilized skim milk concentrate. J Dairy Sci 74:101-107 